\title{
DRUM-TAPS: REVISIONS AND RECONCILIATION
}

\author{
Cristanne Miller
}

MUCH OF THE POETRY WRITTEN FOLLOWING THE CiviL WAR was nostalgic, in the North as well as more predictably in the South, and Walt Whitman's verse does not escape these tendencies, especially in the 1871 revision of his collection of Civil War poems, Drum-Taps. Much prose was similarly nostalgic. D. K. Meisenheimer, Jr., defines the predominant regionalism in post-war prose writing as "elegiac ethnography." This development was not a surprising one considering the times. As David Blight writes in Race and Reunion, during Reconstruction "the forces of reconciliation overwhelmed the emancipationist vision in the national culture" through a virtual war over public memory. ${ }^{2}$ The North as well as the South turned increasingly to nostalgic narratives of idealized antebellum harmonies or of childhood, unifying the white populations in each region but virtually erasing memory of the strong ideological differences over slavery that caused the war and ignoring the ongoing problems of the large freed African-American population in the South. By nostalgia, I mean a perspective that casts the aura of authenticity or idealization upon non-recoverable elements of the past, or-more to the point in the aftermath of the Civil War-upon unrealized or imagined constructions of the past. As Svetlana Boym argues, nostalgia often occurs "as a defense mechanism in a time of accelerated rhythms of life and historical upheavals"-like the Civil War-and involves selective erasure of historical memory. ${ }^{3}$

Luke Mancuso has recently argued that much of Whitman's writing during the war was nostalgic - in particular, the series of articles that Whitman published on Brooklyn history between June 1861 and November 1862, before he moved to Washington, D.C. ${ }^{4}$ Mancuso uses Boym's distinctions between a "restorative" and "reflective" nostalgia to argue that Whitman's nostalgia is the former. The "restorative" or typical nostalgic longs for return to a lost home, or coherent sense of belonging, harkening toward the past, not the future. It was this type of nostalgia after the Civil War that founded the national sense of an 
idealized genteel South epitomized in plantation literature and that, according to Mancuso, made Whitman turn to Brooklyn history as public memory, to an affiliation with the Revolutionary War, and, in Drum-Taps, to poems of recruitment that don't acknowledge divided feelings about the war, even in the North. Ted Genoways's redating of the Brooklyn material may not substantially alter this argument since, even though it was written earlier, Whitman chose to publish it during the war. "Reflective" nostalgia, in contrast, uses memories of the past, idealizations of family and childhood, and other tropes of restorative nostalgia to embrace an ambivalence about the present, questioning narratives of linear (often national) progress through local, competing narratives of memory, facilitating social critique, and pointing toward the future. ${ }^{5}$ Mancuso sees Whitman's antebellum writing as heteroglossic and his war-time writing as homogenous in tone. While parts of this argument are persuasive, I read Drum-Taps differently. As I read it, Drum-Taps (including the 1871 Leaves of Grass sequence called "DrumTaps") is more reflective than restorative in its tone and complicates, even while it participates in, national nostalgic erasures of memory and narratives of progress.

Whitman's nostalgia, as I understand it, lies not in the partisan tone of his recruitment poems or his references to the Revolutionary War (references that abounded in poetry from the South and North throughout the war) but in his post-war reiteration of his antebellum vision of inclusive, loving, national community, as though it actually existed before the war and could survive the war years unscathed. This vision contradicts Whitman's own expressed Union sympathies and ignores the political realities of the post-bellum years. Moreover, the contradiction becomes more pronounced in his 1871 revised "DrumTaps" sequence. ${ }^{6}$ There, rather than presenting the apparently random order of impressions from the war years, Whitman in effect tells a story of Union enthusiasm and war-time suffering, leading not to military or political victory but to ardent desire for reconciliation with the South, a reconciliation based on familial and religious tropes rather than the spiritual vigor and erotic desire that drive the antebellum poems and are still affirmed in several poems in 1865. This story is not so unusual except that it avoids all heroic memorialization of the war and sense of the war's purpose. Consequently, it does not explain why Union soldiers should enlist and continue fighting through several years of unspeakably bloody battle, why they should later love (ex-) Confederates, or what is gained by such reunion. Moreover, many of the sequence's most powerful images are of mourning.

M. Wynn Thomas describes Whitman as having developed a "rhetoric of conciliation" in his early volumes of Leaves of Grass, and it indeed seems clear that by 1860 Whitman had altered some of his 
earlier claims in his continued attempt to construct a poetic that speaks to a united nation. ${ }^{7}$ The reconciliatory aspects of the 1871 "Drum-Taps," however, suggest a change in Whitman's understanding of the individual and political body, not just a desire to placate former Confederates: the elements Whitman had so powerfully "assume[d]" in 1855 have become impossible to take for granted in relation to either the physical or national body. Consequently, even when Whitman makes similar, or the same, claims of exemplary and conglomerate selfhood following the war, they resonate as nostalgic because there is no longer a credible platform for these assertions. There are then two factors at work: on the one hand, Whitman to some extent makes different claims in the 1871 "Drum-Taps" than he had in Leaves of Grass or in 1865; on the other hand, the war's unprecedented slaughter and divisiveness alter the way his (re)conciliatory rhetoric could be heard. As Louis Menand argues, after the Civil War idealism sounded irresponsible or dangerous to those who had witnessed first hand the consequences of antebellum ideological positioning. ${ }^{8}$ To comprehend the project of Whitman's sequence of Civil War poems and its revision requires revisiting his relation to the political scene before the war and the kind of statement he at least initially imagines Drum-Taps will make, as well as what happens to that vision between 1865 and 1871 .

Whitman's 1855 Leaves of Grass attempted, among other things, to define a fully liberated self, bodily and spiritually, through a quasinational composite identity. His 1865 Drum-Taps spoke differently to and for the individual in relation to national identity, despite Whitman's repetition of many of his earlier claims. Drum-Taps was the first book of poetry Whitman had published after 1855 that was not titled Leaves of Grass - suggesting that he may have seen these poems as markedly different from his earlier poems, starting as early as 1863 , when he began writing friends about the volume. According to F. DeWolfe Miller, Whitman reports in May 1863 that Drum Taps is nearly finished; John Burroughs writes a friend in March 1864 that Whitman "expects to bring out his 'Drum Taps' pretty soon" (Miller, xxvi, xxvii). ${ }^{9}$ While ill in July 1864, Whitman writes to William Douglas O'Connor that "I intend to move heaven and earth to publish my 'Drum-Taps' as soon as I am able to go around" (xxvii). Sometime before April in 1865, he printed a broadside with a table of contents-including some poems not in fact included in Drum-Taps when it was printed, probably a few months later. ${ }^{10}$ Whitman finally printed Drum-Taps in mid-April-first as an unmarketed volume before Lincoln's assassination and then with a Sequel that was marketed and sold in late $1865 .{ }^{11}$

For any reader in 1865 familiar with the plethora of war-time verse asserting sectional battle and hero narratives or dramas of mourning 
and death, Drum-Taps must have seemed an odd volume of chaotic responses to non-historical scenes related to but not portraying the war. Because of its lack of descriptive response to the war, the volume has until recently been perceived as largely apolitical and largely independent of Whitman's poetic project - although biographers (and Whitman himself) have emphasized the central importance of the war to the poet's work. From at least the publication of Betsy Erkkila's Whitman: The Political Poet, however, critics have understood Whitman's general project to be political and national, whatever else it may be, and DrumTaps is in that sense completely in tune with Whitman's earlier poems. Yet Drum-Taps does not reflect Whitman's earlier conception of the self in nature as both singular and communal, simultaneously particular, universal, and quintessentially American-understanding "America" both as a geographical entity and as the sign of potential but not necessarily "achieved" democracy. ${ }^{12}$ In Drum-Taps, individuals are soldiers or the witnesses of soldiers, unified more often in death or suffering than through assertion of a living community, and primarily without geographic location.

The 1855 Leaves of Grass was conceived in relation to the growing tensions between Northern and Southern states, as a reflection of nationalist mandates for geographical expansion, primarily realized through the annexation of Texas in 1845, the acquisition of Oregon in 1846, and the war with Mexico between 1846 and 1848 - all of which Whitman supported. ${ }^{13}$ The first poem of Whitman's 1855 volume celebrated a body at once personal, conglomerate, geographic, and national. Its call for individual liberation reflected the expansionist idealism of the 1840s, the United States' "Manifest Destiny" - a phrase coined during that decade. By the same token, Whitman understood personal liberty and representative democracy to be inherently linked-an idea without strong political resonance through the mid-1850s but strongly identified with the North by 1861: the Union must be preserved, the North believed, in order to save the very possibility of democracy in the world, and hence personal liberty. Whitman's enthusiasm over an idealistic version of the grand narrative of historical expansionism thus both grounds a key aspect of the newly conceived "self" articulated in "Song of Myself" and reflects a partisan view of the political divisions that would provide much of the impetus for this poetic project, since Whitman opposed the extension of slavery into new territories. The analogy of the liberated individual to the expanding liberated nation functioned as a banner of division by the time he was writing Drum-Taps, during the war. In the 1850 s, however, Whitman sought to construct a poetry that would so powerfully identify the psychic, sexual, emotional, religious, and physical liberty of the individual with the whole geogra- 
phy and the democratic institutions of the United States that political dissension could be overcome.

The degree to which Whitman insisted on the physical conjunction of the soul, body, and state is illuminated through comparison with Ralph Waldo Emerson's similar identification of personal liberty with social equality or democracy. Emerson implicitly establishes all human beings as spiritually equal through his identification of "Me" as spirit and "Not-Me" as all else, including the variously hued and gendered body; in contrast, Whitman is the poet of both body and soul-as he frequently repeats. ${ }^{14}$ Emerson's philosophy implicitly erases boundaries between the personal and the national: insofar as its impetus is to unify spiritually that which is physically disparate, to bring all souls into willed participation in a single entity (the "Oversoul"), it is a poetics of union, suggestively national through the poet's role as "representative" and task of "Bereav[ing] a tyrant of his will." "Whitman's poetics constructs physical as well as spiritual community within explicitly national union. He sought to overcome inequalities through celebrating the physical conditions, like gender and race, that divide populations socially and politically, and were especially divisive at a time when women were already agitating for greater political rights and slavery was the most volatile issue of the age. ${ }^{16}$ In his 1855 preface, for example, Whitman writes that "The United States itself is the greatest poem" and that every reader's body is potentially both a microcosm of and a participatory figure in that communal whole. Whitman then provides a recipe for becoming a poem, a concept he has already identified as representing largeness, freedom of thought, and the "genius" of anti-hierarchical presence. "This is what you shall do," he says, and then combines spiritual charges ("Love the earth and sun and the animals") with political charges ("hate tyrants"). The recipe concludes: "read these leaves in the open air every season of every year of your life, reexamine all you have been told at school or church or in any book, dismiss whatever insults your own soul, and your very flesh shall be a great poem and have the richest fluency not only in its words but in the silent lines of its lips and face and between the lashes of your eyes." 17 The body figures as the land: the U.S. is a poem and so, potentially, are "you." Every part of the body, even between the lashes of your eyes and like every region of the U.S., is a part of this "greatest poem" or the poem itself writ small.

As these instructions imply, the 1855 Leaves of Grass constitutes an epic argument responding to an increasingly fraught moment of national politics, not an epic tale. It tells not of a nation's founding but of the extraordinary potential of an idealized United States and reader. In this argument, at some level, selfhood, the nationhood of the ideal "America," and "being in any form" are identical in the progressive nar- 
rative of history: to develop one's fullest spiritual being, uniting all parts into a physical unit alive in every feature, is to become a "great poem" and to take on the epic scope of "the greatest poem," America-the only nation that similarly unites disparate parts and peoples through conviction or ideology, not force, ethnicity, or a shared past. In this sense, Whitman addressed citizens of "a modernized everyday promised land" that stood "for something spiritually universal" and therefore could not be split by sectional divisiveness. ${ }^{18}$ At the same time, the increasing threat of civil war was the impetus for constructing a poetics bound to this progressive, national narrative and anticipating its perfect adhesiveness. In 1855, Whitman wrote to prevent division, to prevent war, and he wrote with the conviction that they could be prevented.

It is this optimistic, progressive nationalism, combining expansionist and democratic idealism with a belief that social disaster can be avoided through personal bonding, that so distinctly locates Whitman's poetics in the antebellum period. For Whitman, this poetics is manifest in the body, and he emphasizes the divinity of physical being as such. Whereas Emerson's body is "Not-Me," "each part and tag" of Whitman's "is a miracle": "Divine am I inside and out [. . .] / The scent of these arm-pits is aroma finer than prayer" ( $L G 1855,29)$. Moreover, once the poet is "afoot with [his] vision," the physical body of the United States-its geography, plants and animals-functions metonymically as the union of its wide-spread people, the site "where" the poet witnesses and celebrates life forms distinctive to each region in that most democratic of written forms, the list or catalog, presenting the panther, rattlesnake, alligator, black bear, she-whale, mockingbird, buffalo, and other animals as of equal and vital worth ( $L G 1855,35-37)$. Here, as throughout "Song of Myself," distinction or difference grounds claims of sameness embodied in the U.S. and the speaker's cumulative "I," whether manifest in geography, animals, and plant species, as here, or in types of labor, regions of the country, and gender, ethnicity, or race. Moreover, the "uniform hieroglyphic" of grass growing throughout every region is mapped racially, as a sign of social/spiritual equality and geographical pervasiveness: it grows "among black folks as among white" and tells us that death is "luckier" than "what any one supposed" ( $L G$ $1855,16,17)$. As the soul communes with its body, right down to its arm-pits, and the individual feels "the hand of God" in all nature, life is regenerated by death. In the light of such cosmic communion, Whitman seems to ask, how can Americans of the South, North, and West fail to understand their common gain in a politics of the diverse whole?

Before the war, Whitman imagined all being in relation to progressive or cyclic intensities of intercourse and union. Each individual is both the seat of all feeling and greatness and a mere cipher-a leaf 
of grass - syntactically and pragmatically replaceable in a progressive narrative of humanity and the nation by others fulfilling the same function (the carpenter, the opera singer, the reformer, the paving man). ${ }^{19}$ In this epic, we are simultaneously affirmed in every atom of our individual being and merged with multiple collective nouns, making us indistinguishable from the whole, the poet's collective "self," the people ("black folks" and "white"), the grass, and an ideal America. ${ }^{20}$ Leaves of Grass is not didactic, but it uses largely apolitical figures and registers of language to make a distinctly political claim. Drum-Taps, in contrast, addresses the most politically charged event of the nineteenth century for the most part as though its bloodshed had left only superficial political scars on the national body or on Whitman's assertions about selfhood and nation. The changes of thought in Drum-Taps are revealed less in what Whitman declares and more by what he omits in relation to his repeated assertions. The most striking omission lies in his lack of any forthright statement about the cause of the war or its desired outcome, and in the 1871 erasure of even his 1865 indirect representations of ideological grounding for the war.

As extensive manuscript research by Ed Folsom, Martin Klammer, Matt Miller, Kenneth Price, and others has demonstrated, Whitman conceived of this project from the beginning as attentive to the suffering slave, hence responsive to the national dilemma of slavery as well as the urge toward territorial expansion. According to Miller's new dating of important manuscripts, sometime in late 1853 or 1854 Whitman wrote his first sketch for a "work of some sort" that would become Leaves of Grass in a notebook fragment Miller calls "Med Cophösis." ${ }^{21}$ On these few pages, Whitman drafts in prose what sounds like a rough outline for "Song of Myself," beginning "Novel? - Work of some sort, Play?" and then introducing his basic idea: "instead of sporadic charactersintroduce them in large masses, on a far grander scale [ . . . ] all in huge aggregates nobody speaks alone." In these preliminary jottings, Whitman emphasizes inclusiveness and equality: "Bring in whole races, or castes, or generations, to express themselves - personify the general objects of the creative and give them voice," he writes; "everything on the most august scale - a leaf of grass, with its equal voice." Then, with a drawn pointing hand to mark emphasis, Whitman continues: "voice of the generations of slaves - of those who have suffered" (Miller, 111-112). Price similarly dates to 1853 or 1854 a little-known draft of "Song of Myself" in which Whitman poses questions about prejudicial perception in the U.S., pointing to the lack of reference to black motherhood and childhood in a sentimental era that celebrated both: "Does the negress bear no children? / Are they never handsome? Do they not thrive?" 22 In the 1854 "Talbot Wilson" notebook, Whitman expresses outrage at the 
rape of slave women by abusive owners, and in another early notebook he queries "who shall be the judge [ . . ] of inferior and superior races." 23 As is often cited, just as he turns from writing prose to drafting his new long-lined style of verse in the "Talbot Wilson" notebook, Whitman affirms: "I am the poet of slaves, and of the masters of slaves" and "I go with the slaves of the earth equally with the masters [...] Entering into both so that both will understand me alike." ${ }^{24}$ Price notes that "it is precisely in the tangled world of manuscript and notebook variants that one can find some of Whitman's most compelling treatments of race" (225), and it has been argued that his 1855 edition of Leaves of Grass was more progressive in its reflections on race and national politics than any later edition of his poems. ${ }^{25}$ Despite ample evidence of Whitman's personal racial prejudice, the manuscripts leave no doubt that he composed his epic poem of unities with profound attention to contemporary social injustice and the intent to valorize the humanity of black Americans by including them in his composite "I." 26

The power of Whitman's antebellum project lies in its affirmation and hope, but what it affirmed is precisely what the Civil War called into question-namely, the possibility of individual liberation within an indivisibly spiritual, political, and multi-ethnic union. Similarly, the ample health of the composite national and individual body celebrated so magnificently in 1855 becomes largely unimaginable after the war. More in tune with the times are poems like Dickinson's late 1865 pondering that "Pain has but one Acquaintance / And that is death"; or Sidney Lanier's late 1865 angry lament for the lacerated bloody breasts of Georgia, the South personified; or nostalgic narratives of childhood like John Greenleaf Whittier's wildly popular "Snow-Bound," published in $1866 .{ }^{27}$

In a January 6, 1865, letter to William Douglas O'Connor, Whitman admits an element of this bleak view of the present in his DrumTaps poems: "The book is therefore unprecedently sad, (as these days are, are they not?) - but it also has the blast of the trumpet, $\&$ the drum pounds \& whirrs in it, \& then an undertone of sweetest comradeship \& human love . . . truly also it has clear notes of faith \& triumph." 28 And indeed, despite the sadness, Whitman's antebellum poetic themes and modes prevail in his 1865 volume: comradeship and love, blast and whirr, notes of faith and triumph amid sadness. In 1871, Whitman printed an altogether different four-line epigraph to the section of Leaves of Grass titled "Drum-Taps": "Aroused and angry, / I thought to beat the alarum, and urge relentless war; / But soon my fingers fail'd me, my face droop'd, and I resign'd myself, I To sit by the wounded and soothe them, or silently watch the dead" (LG 1871, 261). Gone are the "notes of faith and triumph" that could only refer to a Union ideology and victory. In 
1871, Whitman still begins the volume with a patriotic "alarum" but, as his epigraph suggests, he has altered the focus of the series through omissions and by rearranging the poems into a narrative moving from early enthusiasm to later lament. This lament then in turn gives way to assertions of reconciled community unpersuasively echoing the claims of his 1855 project while omitting all ambition to include "whole races, castes" or give anyone but white soldiers "equal voice." 29

In the 1865 Drum-Taps, Whitman eschews the discourse of enemies, describes no specific battles, no generals, no heroic deeds, alludes only in abstract terms to the war's causes or goals, and never mentions who is fighting or even who wins the war. But he communicates an openly partisan and local perspective repeatedly, which provides the strongest link between Drum-Taps and typical Civil War poetry. The opening poems declare allegiance to the North unapologetically, and other poems later repeat these calls to battle. The poem originally titled "Drum-Taps" (retitled "First O Songs for a Prelude" in 1881) addresses "O Manhattan, my own, my peerless!" as the city that "led the rest to arms" (DT, $5)$. While the fact that Whitman never mentions the Union or Confederacy might suggest that he is avoiding taking sides, the celebration of men arming in Manhattan here and in other poems only shows how deeply he assumes allegiance to the Union. ${ }^{30}$ Genoways claims that the poems written early in the war "admit Whitman's own early enthusiasm for the conflict, before initiating readers into the harsh realities to follow"-and this is largely the case in 1871 ("Civil War Poems," 523). They also, however, set a partisan tone, reinforced in 1865 by the fact that these poems are not clustered at the beginning.

This assumed allegiance reveals itself in multiple aspects of Whitman's lack of detail: he refers not to the "stars and stripes" as opposed to the Confederate "stars and bars"-wordplay common to contemporary popular poems - but to "the flag," as though there could be only one $(D T, 7)$. The contextual impact of the first poem is obvious in the second. "Shut not your doors to me proud Libraries" (omitted in 1871) claims that the speaker brings "that which was lacking among you all, yet needed most," addressing "soldiers" and "arm'd Libertad," thereby suggesting that "what is needed most" is the joy of arming against a threat to the Union, "Libertad" personified $(D T, 8)$. In these poems, Whitman also continues his earlier rhetoric of the love of comrades, but now his comrades are partisan fighters: "How I love them! how I could hug them," he exclaims of the enlisting soldiers in the poem "DrumTaps" and his gift to the "Libraries" is "for your dear sake, O soldiers / [. . .] and you, love of comrades" (DT, 6, 8).

"Song of the Banner at Day-Break" (also omitted in 1871) begins with the "Poet"-speaker's claim that the "flapping" of the flag gives 
it "a new song, a free song // [....] Words no more, for hearken and see, / My song is in the open air"-presumably on the march with the army, since this poem immediately follows "Cavalry crossing a ford," which ends with the line "The guidon flags flutter gaily in the wind" $(D T, 9,8)$. Later the "Poet" is identified as the "bard, out of Manhattan" and exhorted to "speak to our children all, or north or south of Manhattan"- that is, to call all loyal to the U.S. flag to join in "the tramp of armies" (DT, 11-12). The flag itself then articulates the Union platform: "Not now are we one of these spacious and haughty States, (nor any five, nor ten;) [. . .] / But these, and all, [...] are ours / [... .] the three millions of square miles [. . .] / for a thousand years"; the nation remains unified and the flag represents all states, not just those that did not secede $(D T, 13)$. No reader of the mid-nineteenth century could mistake this for anything but partisan rhetoric, countering early Confederate poems that count the increasing number of seceded states. ${ }^{31}$ In all versions of Drum-Taps, some poems mourn the death of Southern as well as Northern men but in 1865 Whitman openly associates "Libertad" with Northern victory and Union, and celebrates the enlistment of troops in New York. Because in 1865 the recruitment poems are interspersed with poems of mourning and doubt about the war's conclusion, the sequence functions heteroglossically as a whole, shifting back and forth from largely partisan responses to reconciliatory or descriptive reflections rather than narrating a story of the war.

In 1871, Whitman omitted twenty-four poems permanently from Drum-Taps, moved six poems from the Sequel into the primary sequence, and added only one new poem and the epigraph previously quoted. ${ }^{32}$ The previous Sequel became a much shorter separate section titled "President Lincoln's Burial Hymn" (seven poems from the sequel were omitted from both "Drum-Taps" and the new Lincoln section). An additional four poems were omitted from "Drum-Taps" in 1871 but returned to the sequence in 1881 . In short, the 1865 book of fiftythree poems (not including Sequel) became a vastly different sequence of thirty-two poems in 1871. The twenty-eight poems omitted in 1871 include most of those which are clearly anachronistic ("A Broadway Pageant," "When I Heard the learn'd Astronomer"), several three- to eight-line descriptions like "Mother and babe," "A child's amaze," or "A farm picture," which most critics have regarded as filler, designed to enable major poems to begin at the top of a page while filling all white space, and the (homo)erotic and most ideologically partisan poems. ${ }^{33}$

Whitman's recruitment poems are among his most partisan. Among those omitted in 1871, "Bathed in war's perfume" refers to the "joy" of arming for war and compares the "delicate flag" to "a beautiful woman" in its seductiveness; "Year of meteors/ (1859-60)"-which comes about 
half-way through the 1865 sequence-presents the incendiary John Brown as a martyr. "Song of the Banner" functions as a recruitment poem in the 1860 s but might well have been read by 1881 (when it was returned to the sequence) as more inclusively patriotic. "World, take good notice"-also omitted in 1871 and returned to the sequence in 1881 - sends a "hands off warning" "Now and henceforth" to the world $(D T, 67)$. In 1865 or 1871 , this warning could only have been read as referring to the Confederate hope that England and France would intervene on their side and Lincoln's threat that the U.S. would declare war on any country that did so; by 1881 , this historical grounding might have been forgotten. "Hush'd be the camps today," with its reference to "Our dear commander's death" and "the love we bore him," known especially by "you, dweller in camps," was moved to "President Lincoln's Burial Hymns" (DT, 69). While many in the South might have mourned Lincoln's death by 1871, they would not have acknowledged him as "Our dear commander," nor would he have been particularly dear to Confederate soldiers. Union soldiers, in contrast, voted overwhelmingly for his reelection in 1864. As these poems suggest, much that would have been read as partisan in 1865 has no concrete reference for most twenty-first-century readers, hence it is hard for us to hear the sequence as Whitman's contemporaries would have read it and to note the difference these omissions make in the 1871 sequence.

The most telling omissions are those that hint at some purpose to the war. In "Years of the unperform'd," which was retitled and moved to another sequence, the speaker claims to "see not America only-I see not only Liberty's nation, but other nations preparing" for the progressive march of history, in which Freedom is flanked by Law and Peace, and "issu[es] forth against the idea of caste." " Then Whitman articulates the expansionist vision of his earlier poems through prophecy: "I see [...] old aristocracies broken," and "the average man['s] [...] foot is on land and sea everywhere-he colonizes the Pacific, the archipelagoes; [...] he interlinks all geography, all lands" $(D T, 53)$. "Years prophetical!" Whitman exclaims, evidently seeing the war between the states as a sign of world-wide (as yet "unperform'd") revolution: "Is humanity forming, en-masse? - for lo! tyrants tremble, crowns grow dim; / The earth, restive, confronts a new era, perhaps a general divine war" (DT, 54). While Whitman writes similar prophecies at other points in his career, in the context of the Civil War the South is unambiguously the aristocracy to be broken; slavery is the "idea of caste" rejected; abolition heralds "the solidarity of races," and all under the joint authorship of Freedom and Law - that is, the national law the non-seceding states sought to enforce. Also retitled and moved to another sequence, "Flag of stars" similarly looks toward a future when the "flag of man"-the 
U.S. flag - passes the "highest flags of kings" that have again "dream'd" of flying unrivalled. This trope is based on the fervent Union belief that to allow secession was to admit the failure of the democratic experiment forever, and hence to witness a return to non-representative government. "Turn O Libertad" also calls liberty to turn away from "doubting [. . . ] / From the chants of the feudal world - the triumphs of kings, slavery, caste; / [ . . ] that backward world" (DT, 70) and toward a future that is undescribed but implicitly democratic. Although the 1865 volume gives no chronological narrative, the fact that this poem appears fourth from the end and following "Hush'd be the camps" (subtitled "A.L. Buried April 19, 1865") suggests that it celebrates the abolition of "backward" slavery and a future dominated by the North or Republican party (DT, 69). Although this and other such claims are unostentatious, occurring in the middle of poems and not highlighted through repetition or specific scenes or portraiture, the fact of their presence scattered throughout the volume in 1865 makes this a collection hewing closer to a celebration of Union ideology and victory than the 1871 revision, hence modifying the nostalgic aspects of its assertions that the U.S. was or would be again fully united; in this volume, such assertion does not altogether erase the political causes and outcome of the war.

"Years of the unperform'd" exclaims in 1865 that "Never were such sharp questions ask'd as this day; / Never was average man, his soul, more energetic, more like a God" (DT, 53) — a claim reflected in much of Whitman's poetry presenting the Civil War as manifesting the ordinary man's triumph and vindication, and at least hinting at the "sharp" ideological divisions between Confederates and Republicans, or Republicans and Copperheads in the North. In contrast, in a poem moved to another sequence, "Quicksand years that whirl me I know not whither," the speaker feels overwhelmed by a horrible sucking ooze of doubt that allows no escape. Whitman admits to having lost his bearings in this poem, presumably referring to the doubts of the war years. To recover his self-possession, he asserts "Only the theme I sing, the great and strong-possess'd soul, eludes not [. . . / Out of politics, triumphs, battles, death - what at last finally remains? / When shows break up, what but One's-Self is sure?" (DT, 30). In "Song of Myself" the "self" trumpeted was always in relation: "It is you talking just as much as myself . . . I act as the tongue of you"; "These are the thoughts of all men in all ages and lands ... If they are not yours as much as mine they are nothing" ( $L G 1855,53,24)$. In "Quicksand Years," in contrast, the speaker's "I" is ostentatiously singular: "One's-Self," a hyphenated compound capitalizing both words. This is the self vulnerable to death, also a singular event even when occurring on a massive scale. The individual is now vulnerable to a deeply mourned death, no longer 
a substitutable element of a celebrated whole - a paradoxical change, since the soldier's is the most substitutable of professions - and death on this scale is not "lucky." Although Whitman placed "Quicksand Years" in another sequence of poems in 1871, it voices the assumption of individual frailty and loss that underlies the new story of "Drum-Taps."

Whitman retains some partisan poems in 1871, but moves them to the beginning of the sequence where they seem to reflect a passing moment in time rather than his overall stance on the war. "Rise, O Days, from your fathomless deeps," for example, calls on "Democracy" to "strike with vengeful stroke," and claims that the passions of war "fill" "our latent and ampler hunger"-presumably that of the North, since both sides cannot be unified in "our" vengeance-but now as the fifth not the fourteenth poem. "Beat! Beat! Drums!" is also moved to the beginning of the sequence, as is "City of Ships," where Whitman proclaims love for a port city that can only be Manhattan. Here his love tallies what he professed in "Song of Myself" for the U.S.: "City of the world!" he calls it, "(for all races are here; / All the lands of the earth make contributions here;)." And later he writes: "Incarnate me, as I have incarnated you! / [....] I chant and celebrate all that is yours-yet," he interrupts himself, "peace no more / [ . . . W War, red war, is my song" (DT, 41). In this poem, Manhattan, not the nation, contains the mergings of world-wide diversity. These poems join "Drum-Taps," "1861," and the resonantly antebellum "From Paumanok Starting" as the first six poems of the sequence. The seventh poem is "The Centenarian's Story," linking Union volunteers to the patriot soldiers of the Revolutionary War. Thereafter there are no recruitment poems and only "Give me the Splendid Silent Sun" speaks specifically from and on Manhattan. The 1871 sequence then turns to mourning, descriptions of woundings or death, and reconciliatory language without reference to the war's causes or purpose.

While reconciliation is not in itself a nostalgic project, the powerfully reconciliatory poems that Whitman moved from Sequel to the end of "Drum-Taps" in 1871 contribute to the misleading assumption that the States can easily be - or are already effectively, and not just militarily-unified. Because Whitman has omitted ideological claims of any specificity, the war seems to be an aberration rather than the result of deeply held convictions, and there is consequently no logical hindrance to reunification. Drum-Taps concludes casually, with three poems that neither celebrate nor lament the war: the descriptive "Bivouac on a Mountain Side" (moved much earlier in the sequence in 1871); the elegiac "Pensive on her dead gazing, I heard the Mother of all" (moved to another sequence in 1871); and "Not Youth pertains to me" (revised in 1871). "Pensive on her dead gazing" mourns "the torn bodies on [. . . battle-fields" whose bones, blood, and every atom are to be ab- 
sorbed by the earth. "Not Youth pertains to me" concludes in 1865 with the line: "at intervals I have strung together a few songs, / Fit for war, and the life of the camp," a conclusion that provides no ideological or narrative purchase. ${ }^{35}$ In contrast to this low-key and largely descriptive conclusion to the volume proper the 1865 Sequel concludes with heavy emphasis on reconciliation. In its final three poems, "Lo! Victress on the Peaks!" claims that "the world," not the "South," "vainly conspired against" liberty (SDT, 23). "Reconciliation" follows "Lo! Victress," followed in turn by "To the leaven'd Soil they trod," where the poet emerges from his tent "To the fiery fields emanative, and the endless vistas beyond - to the south and the north," all "to peace restored." Moreover, the speaker announces in the poem's last line that he needs "the hot sun of the South [. . .] to ripen my songs" (SDT, 24). In 1871, "Reconciliation" and "To the leaven'd Soil they trod" are moved forward into "Drum Taps," foregrounding the message of appeasement; with this shift it is not "Libertad" but "Reconciliation" that is the "Word over all" (SDT, 23). ${ }^{36}$ In "Spirit whose work is done" (also moved from the sequel to "Drum Taps" in 1871), the speaker urges not Northern soldiers but the "spirit" of war, generally, to "Leave me your pulses of rage [. . .] / Let them scorch and blister out of my chants, when you are gone," seeking to absorb all remaining enmity of both sides of the conflict $(S D T, 14)$.

Through such changes, Whitman condenses Drum-Taps, making it less a record of patriotic partisanship and doubt supporting both an ideal and an immediate United States free of slavery and more a story of a war's protection of never-defined "democracy" that leads to fraternal mourning for the South's and North's equally "divine" dead-soldiers who have died for no apparent cause since there is no explanation of why states would either secede or fight to prevent secession in the first place. In the 1871 "Drum-Taps," there is no reference to international revolution, to a national merging or solidarity of races, and there are (still) no African Americans. The entire issue of slavery, so urgently presented through the portraits of hounded and rebellious slaves and the beautiful black body in 1855, appears with extreme indirection in 1865, not at all in 1871, and in only one poem in 1881, "Ethiopia Saluting the Colors." Speaking briefly in the voice of a black woman whom he, or his soldier-speaker, describes twice as "hardly human," Whitman does not pretend here to speak for, understand, or call to African Americans as part of a national family or even as part of the geographical "South" that will "ripen" his poems. ${ }^{37}$ Instead, the poem expresses frank bafflement at the perspective of the African American witnessing (not contributing to) Northern victory, asking "Are the things so strange and marvelous you see or have seen?" ( $L G 1881,249) .{ }^{38}$ While omission of all mention of black Americans is as striking in 1865 as in 1871, the earlier volume 
at least fleetingly presents liberty as waging a "war against caste" and slavery, even while it seems, briefly, to accept the fact of slavery as it celebrates, "all the masters with their slaves" participating in America's westward march in "Pioneers! O Pioneers!" (DT, 28, omitted in 1871).

In "Drum-Taps," the U.S. is no longer a poem, and individuals are celebrated as sacrificial martyrs, not as beings spiritually alive in every particle of their being. The body, here, is maimed, vulnerable, and love is expressed most strongly for the comrade who has died, not for a potential or real lover. While the 1865 Drum-Taps and Sequel still contain several poems asserting the speaker's role as "lover and hero," they are largely dropped in $1871 .{ }^{39}$ Consequently, rather than building a homoerotic community or engaging in an intercourse of body with soul, the speaker of "Drum Taps" is by and large bodiless, in a mode traditional to lyric and epic poetry and utterly unlike Whitman's speaker of the 1855 Leaves of Grass. Where that speaker identified with slaves and prostitutes, reveled in sexual and physically imminent nakedness, and asserted that the kind of unity sought by the poet discriminated against no profession, race, or class, the 1871 speaker (after the initial recruitment poems) identifies primarily with the dead or with men's souls. Rather than the repeated assertions of 1865-"all now is over; / But love is not over - and what love, O Comrades" ("Hymn of dead soldiers," DT, 59) or reference to "Year of the youth I love" ("Year of Meteors" DT, 51) — in 1871 the only kisses are for ghost-like forms or the dead: for the "boy" or "son of responding kisses, (never again on earth responding)" in "Vigil Strange I Kept .. ." or the "white-faced" dead "enemy" in "Reconciliation" ( $L G$ 1871, 281, 295). Two of the last four poems in the 1871 sequence welcome "returning" soldiers to "Washington City"-logically Union soldiers since they return to Washington. In "Spirit Whose Work is Done," however, Whitman addresses only the "Spirit" of war, not the "young men" he sees marching and he calls to the spirit to "Touch my mouth, ere you depart-press my lips close!" Similarly, "How Solemn, as One by One" presents a universalized "kindred soul" behind the "mask" of each soldier's face: "The soul! yourself I see, great as any, good as the best, / Waiting, secure and content, which the bullet could never kill, / Nor the bayonet stab, O friend" - a stark contrast to Whitman's earlier invitation that each reader join him, physically, on the road or his assertion that he sees even future readers "face to face" on the Brooklyn ferry $(L G 1871,297)$. The final poem in 1871, "To the Leaven'd Soil They Trod," calls for regional reunion not in the form of men loving men, but as amorphous inspiration, to launch the (singular) poet's songs: "The prairie draws me close, as the father, to bosom broad, the son; / The Northern ice and rain, that began me, nourish me to the end; / But the hot sun of 
the South is to ripen my songs" ( $L G 1871,298)$ Despite the retained optimistic prophecy of "Over the Carnage"-that "Affection shall solve the problems of Freedom yet; / Those who love each other shall become invincible" ( $L G 1871,292)$ - the volume as a whole disembodies this love among the living. In "To the Leaven'd Soil they Trod" the nation's reunion takes place in the poet's mind and through a partially drawn familial unit: the West acts as father, and both North and South take the maternal roles of nourishing and ripening, although neither is named as mother. Such unproblematized reconciliation can take place only through erasure of the memory of slavery, of the presence of freed and terrorized blacks in the South, and through a body and soul so fully committed to reunion that there are no conditions for the requested merging. Where the speakers of "Song of Myself," "Song of the Open Road," and the "Calamus" poems call only to those willing to accept their unconventional terms, the speaker of the 1871 "DrumTaps" sequence loves all who have died and hence unites with all who are mourning the "white-faced" dead.

Popular poetry written immediately following the war typically divides into clear political categories. Southerners like Lanier, Henry Timrod, and William Gilmore Simms mourn the death of the southern nation without abandoning in the least the ideals for which it fought. They present themselves as a conquered and wronged people, comparable to other people of great fallen nations. For example, in a Timrod "Ode," the confederate dead are "martyrs of a fallen cause" comparable to the ancient Britons awaiting their King Arthur: "And, somewhere, waiting for its birth, / The shaft is in the stone." ${ }^{40}$ In "Ay de Mi, Alhama," Simms more aggressively writes, "Though often crost . . . No cause is lost, my Dixie Land! / While still remain a generous Host; / That hold the Faith, that keep the post"; the poem then concludes that "Though faint and few ... We keep the Faith our Fathers knew, / For which they bled, in which we grew, / And at their graves our vows renew" (189). This is not a poem of reconciliation but of defiant commitment to Confederate ideology, called "truth" and presented in the religious language of "Faith." African-American poets write with similarly open political allegiance, but they celebrate black citizenship and those responsible for the war's outcome-primarily Abraham Lincoln, but also Union generals and African-American soldiers. Northern white poets, however, many of whom condemned slavery and Confederate betrayal before and during the war, now write of reconciliation.

The anonymous "The Voices of the Guns" exemplifies this genre, in that it even models for its readers the way to turn to "forgiveness" rather than harboring bitterness and hate. At the war's end, the speaking soldier hears "A Godlike word of hope and cheer: / Forgiveness" and responds at first with angry refusal: 
I thought of Shiloh's tainted air,

Of Richmond's prisons, foul and bare,

And murdered heroes, young and fair,-

Of block and lash and overseer,

And dark, mild faces pale with fear,

Of baying hell-hounds panting near.

"But then," the soldier has a vision of familial reconciliation dissolving his righteous anger. These thoughts make him exclaim:

O prodigal and lost! arise,

And read the welcome blest that lies

In a kind Father's patient eyes!

Thy elder brother grudges not

The lost and found should share his lot,

And wrong in concord be forgot. (Words for the Hour, 166)

In this poem, the Christian parable of the Prodigal Son provides the basis for "concord" and "forgiveness," not renewed ideological vows, and dictates that remaining wealth be shared with the rebellious son of the "Father"/nation and North's younger "brother." Like the speaker of this anonymously authored poem, Whitman begins his 1871 sequence in a partisan mode and ends with an emphasis on reconciliation and brotherhood, apparently already "forgetting" the "wrong" of slavery over which the war was in large part fought. In the 1865 Drum-Taps, Whitman already refers to a corpse as "Dead and divine and brother of all" in "A sight in camp in the daybreak gray and dim." Moving "Reconciliation" into the "Drum-Taps" sequence proper in 1871 reinforces this universal claim since there the speaker regards a dead "enemy" as "divine as myself" - hence of one human family, commonly "divine." In 1881, Whitman includes his most specific poem on this topic, "Virginia-The West," a poem drafted early in the war. ${ }^{41}$ In "Virginia-The West," the "noble sire" (Virginia-home of Washington and Jefferson) has "fallen on evil days" and brandishes an "insane knife toward the Mother of All," elsewhere identified as democracy. It is the "knife," not the "sire" that is "insane," and curiously the blue-clad collective "noble son" of the West marches "to rescue the ['rebellious'] stalwart giant"-presumably the sire-as much as the Mother. Rebellion itself (the "insane knife") and "evil times" are to blame-not Virginia or the South, and the political Union is naturalized as a nuclear family, in which the North has no apparent role except, perhaps, as witness or bard.

Yet even the 1871 "Drum-Taps" sequence is not simply nostalgic. Despite being clustered at the beginning of the sequence, the partisan 
poems remaining in "Drum-Taps" call into question Whitman's credibility in affirming his representativeness as the poet of the South as well as the North at the end of the sequence - an assertion already problematic in 1855 but far more so after Whitman has called for "red war" against the Confederacy. For example, "1861" describes this "arm'd year" as "a strong man, erect, clothed in blue clothes," personified by men from Manhattan, the West, and Pennsylvania, but no farther south than "the Tennessee or Cumberland rivers," areas of Union support ( $L G 1871,264)$. Following such a poem, the claim that "the South" will ripen the poet's songs sounds either nostalgic of a past imagined pastoral harmony or simply contradictory in perspective rather than hopeful for a profoundly imagined future. Similarly, Whitman's assertions of unity under the banner of "Libertad" resonate as illogical as much as nostalgic since the country is unified only through military occupation in 1871, and the freedom advocated by Confederate rhetoric was precisely freedom from the "tyranny" of the North: the words liberty and tyranny were used by both sides during the Civil War with different meanings - as Whitman the journalist would of course have known.

"Democratic Vistas," written between 1868 and 1871, is similarly contradictory in its representations of the war and the U.S. Here Whitman declares that the Civil War validates his claims about "popular democracy" by embodying it in a largely volunteer army of "The People" who defend that democracy. ${ }^{42}$ Union soldiers are repeatedly described in non-sectional terms ("people," "the American-born populace"), as though the "secession-slave-power," as Whitman calls it, is not also a defining part of the American people. Similarly, Whitman isolates the "secession-slave-power" from any geographical region rather than identifying it with the South, allowing him to assert continued unity of all regions of the U.S. and ignore the ongoing role of Federal troops ("the people"?) in putting down continued violence in the South. This is a part of what distinguishes "Drum-Taps" and "Democratic Vistas" from the 1855 Leaves of Grass: there is no profound grounding in the immediate political scene of the nation, or rather such grounding is constituted largely by its participation in a Northern liberal turn toward nostalgia. In "Democratic Vistas," Whitman both acknowledges the bitter sectional divide leading to war and erases it through repeated praise of Americans, "the peaceablest and most good-natured race in the world," concluding that "the proof on this point comes . . . every bit as much from the south, as from the north"-regions writ small to signal their merely geographical, not ideologically sectional, significance. ${ }^{43}$ Like colonial revivalism or myths of a genteel South, such rhetoric for the most part nostalgically constructs visions of a future from a simplified homogenous present and past, although its insistence on the heroism 
of ordinary men in defeating the "secession-slave-power" contradicts that implied homogeneity. ${ }^{44}$

The pattern of contradictions are what make Whitman's post-war nostalgia reflective rather than restorative, to return to Svetlana Boym's useful distinction. The most obvious pattern is that between partisan and reconciliatory nation-building, but Drum-Taps contains other types of contradiction as well. Both Drum-Taps and the more nostalgic 1871 "Drum-Taps" sequence contain passages of shocking realism. ${ }^{45}$ While some dead are described as "divine" martyrs, "The Dresser" recounts memories of the wounded with "bloody stump [s] [....] gnawing and putrid gangrene," and other poems present a "crowd of the bloody forms of soldiers" ("A March in the Ranks ...") and the myriad dead's "faces ghastly, swollen, purple" ("Look Down Fair Moon"), all of which are part of the price of political reunion ( $L G 1871,287,281,295)$. Here Whitman departs both from his own narrative of reunion, which understandably omits reference to war's butchery, and from popular Civil War poetry, very little of which portrays the conditions of the wounded with realistic detail. Moreover, at the end of "Drum Taps" cultural reunion remains merely potential: the South "is to ripen" his songs; the ripening has not yet occurred (my emphasis). Despite his assertion of brotherhood and human divinity, the nation Whitman depicts in 1871 no longer has a representative "self" exuding optimism and health: individuals are not linked through bonds of potent physical being in the natural world, and one poem even acknowledges that there was no ideal wholeness in the past any more than at present. In "Reconciliation," the "hands of the sisters Death and Night, incessantly softly wash again, and ever again, this soil'd world," renewing the world but admitting that the past was also always "soil'd" with "deeds of carnage" ( $L G 1871,295)$. The poem, then, both asserts unequivocal desire for reconciliation and keeps alive some of the memories that would make it difficult.

Another powerful contradiction arises from Whitman's tenuous remaining assertions of homoerotic community in 1871. In 1865, Whitman's poignant assertions of a utopian future still repeatedly reflect his antebellum proclamations of homoerotic adhesiveness. By 1871, the vision of a community unified through love appears in far fewer poems and has become more nostalgic because it must ignore so much to reach its desired conclusion: the end of the war has not brought affectionate reconciliation, the South remains occupied territory, and African Americans live in increasing fear of marauder violence. While Whitman's vision of affectionate male bonding was always idealistic, it now has no resonance with a realistically viewed present. Yet despite his omission of all poems in which the speaker declares outright "love" for individual or multiple soldiers, his demonstrative kiss of the "enemy" still implicitly disrupts culturally dominant narratives of reunion as 
courtship or marriage between a feminine South and manly North by asserting a competing masculine "love of lovers" that refuses to function merely as a rhetorical figure ("Over the Carnage" $L G 1871,292$ ). Although in the 1871 "Drum-Taps" the remaining assertions of such love are primarily for the dead, they nonetheless articulate a passion that had characterized the living and now elegiacally lingers as a model of masculine behavior. In 1871, Whitman also moves one of the most powerful of these non-sectional portraits of men grieving the death of men from the sequel to the main sequence: "Dirge for Two Veterans," with its closing lines, "And my heart, O my soldiers, my veterans. / My heart gives you love," joins "Vigil Strange," "A Sight in Camp," and "As Toilsome I Wander'd" in depicting men expressing love for dead soldiers. Moreover, two poems retained in the 1871 sequence openly reiterate Whitman's earlier, broader claims. In "Over the Carnage," Whitman prophesies that "Affection shall solve the problems of Freedom yet; / Those who love each other shall become invincible," and "Columbia's lovers" shall cross all sectional lines in their "manly affection." In "O Tan-faced Prairie-Boy," placed later in the sequence, this general call for "manly affection" takes realized form between individuals: the speaker and a taciturn new recruit "but look'd on each other," causing the speaker to exclaim: "more than all the gifts of the world, you gave me" (LG 1871, 295). ${ }^{46}$

In 1871 , Whitman defines victory not politically or ideologically but as a battle opposed only to abstractions like hatred and divisiveness, leaving in its wake heart-felt love for the dead, implying a similar love among the men who continue to live. Such a love is possible only if the war is imagined as fought between and for white men, since the introduction of slavery or a freed black population into this picture would disrupt its figures of intimacy, where men are at least metaphorical "sons" and "brothers" as well as lovers. The poem also, however, leaves gruesomely realistic memories of carnage with its readers. Together, the intensely future-focused longing of the narrative's conclusion, its refusal to disguise the past's bloodiness even while it erases the past's ideological divisions, and the competing narratives of national familial and homoerotic affection make the nostalgia of "Drum-Taps" reflective; it troubles the relation of the present to both past and future.

Read as reportage or reflection on the war, Drum-Taps is puzzling in its internal contradictions and omissions of specific historical reference, differently but almost equally in its 1865 and 1871 versions. Read as an attempt to reconstruct a vision of an ideal United States out of the rubble of four years of battlefield slaughter and embittered ideological division, it is a powerfully complex sequence alternating nostalgic claims that Whitman's past vision for the U.S. is not just possible but 
still manifest with moments of painful realism. Read as an intervention in a moment of increasingly nostalgic Northern rhetoric about the returning prodigal brother, it is a document of deeply shared longing for such reunion but through the corrective bond of homoerotic companionship (or mourning) and at least periodic realistic acknowledgement of the mutilated bodies and psychic suffering on and out of which the reunified Republic must be built.

After 1871, Whitman's poetry continues to reiterate calls for the merging of people, regions, and nations but without the exhilarating grounding of that vision in physically manifest relations of affection and desire. Similarly, his assertion of political and geographic unities no longer has the edge of risky political affiliations that gave his poetry of the 1850 s such force or made Drum-Taps so troubling. In the 1865 DrumTaps, Whitman attempts to balance celebration of the overwhelming Union response to Lincoln's first calls for volunteers during 1861-1862 that he found so heartening, his anguish over the mutilations and deaths of the war, and the collapse of his antebellum vision of political and affectional unities. By the time he prints this volume, he has retreated from his strong 1855 assertions of political equality and freedom but continues to speak as "lover and hero," presenting less a portrait of a nation than of a speaker-witness who is both confused and full of love for the men he sees everywhere. By 1871, the volume has become more nostalgic and Whitman has significantly narrowed the political implications of his reaffirmed ideal through his insistence on reconciliation, yet he continues to affront the reader with scenes of agonizing surgery and dying and post-traumatic stress nightmares (the "falling, dying [. . .] wounded, dripping and red" in "The Artilleryman's Vision," LG $1871,294)$ as well as of elegiac, homoerotic mourning and longing for a new, equally powerfully bonded but non-military community. The greatest strength of Drum-Taps in all versions is that even in his nearly compulsive effort to celebrate a still-unified nation, Whitman represents powerfully the bloody cost of the war and the not altogether successfully repressed "dripping and red" memories it leaves, not just with "The Dresser" and the artilleryman but with the nation for decades to come.

State University of New York at Buffalo 


\section{NOTES}

1 D. K. Meisenheimer in "Regionalist Bodies/Embodied Regions: Sarah Orne Jewett and Zitkala-Sa," Sherrie A. Inness and Diana Royer, eds., Breaking Boundaries: New Perspectives on Women's Regional Writing (Iowa City: University of Iowa Press, 1997), 121. My thanks to Maura Pellettieri for her assiduous research assistance in preparing this essay.

2 David Blight, Race and Reunion: The Civil War in American Memory (Cambridge: Harvard University Press, 2001), 2, 57.

3 Svetlana Boym, The Future of Nostalgia (Cambridge: Harvard University Press, 2001), xiv.

4 Luke Mancuso, "Civil War," A Companion to Walt Whitman, ed. Donald D. Kummings (Oxford: Blackwell, 2008), 293-298. In contrast, Ted Genoways has established that almost all of this material was written by the early 1850 s, when Whitman was planning a book on "Brooklyniana"- that is, long before the war and obviously not in response to it (personal correspondence October 29, 2008).

5 Jennifer Ladino calls this a "counter-nostalgia" and claims that it "revisit[s] a dynamic past ... to invert or exploit official narratives in ways that challenge dominant histories" and "facilitate social critique"; "Longing for Wonderland: Nostalgia for Nature in Post-Frontier America," Iowa Fournal of Cultural Studies 5 (2004), 91, 89.

6 Henceforth, I distinguish Drum-Taps, the book printed in 1865, from "Drum-Taps," the sequence included in Whitman's 1871 Leaves of Grass.

7 In particular, Wynn Thomas argues that Whitman omits from the 1860 edition drafted lines including an incendiary description of the mistreatment of slaves, substituting language suggesting slave holders were more benign. See M. Wynn Thomas, "Whitman and the Dreams of Labor," Walt Whitman, The Centennial Essays, ed. Ed Folsom (Iowa City: University of Iowa Press, 1994, 140-141. See also Ed Folsom's reiteration of this argument in "So Long, So Long: Walt Whitman, Langston Hughes, and the Art of Longing," in David Haven Blake and Michael Robertson, eds., Where the Future Becomes Present (Iowa City: University of Iowa Press, 2008), 127-143. Quoting Whitman's own words, Folsom argues that Whitman saw his 1860 edition as his "American Bible," intended "to hold North and South together" (127).

8 Menand, The Metaphysical Club: A Story of Ideas in America (New York: Farrar Straus Giroux, 2001), xii.

9 F. De Wolfe Miller, Walt Whitman's Drum-Taps and Sequel to Drum-Taps: A Facsimile Reproduction (Gainesville, FL: Scholars' Facsimiles \& Reprints, 1959), xxvi, xxvii. All quotations from Drum-Taps (hereafter DT) and "Sequel to Drum-Taps" (hereafter $S D T$ ) will be taken from this volume and follow Whitman's original pagination, which begins again with 1 on the title page to the "Sequel." Because Whitman is inconsistent within this volume about capitalization of letters in his titles (using few capitals on his title page, and often uniform-sized lettering in the title preceding each poem in the text), I follow his capitalization in the table of contents.

10 Michael Warner reprints the undated placard for "Walt Whitman's New Volume of Poems. DRUM TAPS" in "Civil War Religion and Whitman's Drum-Taps," Where the Future Becomes Present, 83; see also DeWolfe Miller, xxxii-xxxiii. 
11 Whitman hired a printer for Drum-Taps in April 1865; before the pages were bound, however, Lincoln was assassinated and Whitman withdrew the book before it was circulated-adding twenty-four pages of poems, some of which were written before the assassination, as is clear from the early 1865 broadside (DeWolfe Miller, xxx-xxxi; Warner, 82). These new pages were bound with the previous ones in a single cover containing Drum-Taps and "Sequel to Drum-Taps." A volume with only the initial Drum-Taps poems was probably never distributed.

12 Horace Traubel quotes Whitman at length to argue that Whitman was a patriot not of the United States but of an ideal, which he recognized the United States might fail to accomplish and which might be accomplished in some other nation "perhaps by some other name"; "Walt Whitman's America," The Conservator 28 (November 1917), 134; rpt. Gary Schmidgall, ed., Conserving Walt Whitman's Fame (Iowa City: University of Iowa Press, 2006), 29.

13 Betsy Erkkila, Whitman the Political Poet (New York: Oxford University Press, 1989), 39.

14 Emerson does not himself affirm these implications and in fact contradicts them in other aspects of his writing.

15 "The poet is representative. He stands among partial men for the complete man, and apprises us not of his wealth, but of the common wealth" ("The Poet," 223); see also "Merlin," 448, in Selections from Ralph Waldo Emerson, ed. Stephen E. Whicher (Boston: Houghton Mifflin, Riverside, 1957).

16 Despite his frequent language of inclusion, much of Whitman's language draws from the same masculinist norms as Emerson's; moreover, several critics have argued that Whitman's prevailing concern is with white male laborers, and his language predominantly heralds the equality of "men." See, for example, Thomas's "Whitman and the Dreams of Labor." Vivian Pollak also deals at length with Whitman's class-conscious attempted identification as "one of the roughs" in The Erotic Whitman (Berkeley: University of California Press, 2000). "Racial justice mattered to him," she notes, "but it was far from his most important issue" (125).

17 This passage appears on pages v-vi of the preface of the 1855 edition of Leaves of Grass, hereafter abbreviated in the text as $L G 1855$, with page references to the on-line facsimile text. Other editions of Leaves of Grass are similarly abbreviated (e.g., $L G$ 1871). Available on the Walt Whitman Archive (www.whitmanarchive.org).

18 Traubel, "Walt Whitman's America," 27, 26.

19 Wai Chee Dimock makes this argument in "Whitman, Syntax, and Political Theory," in Betsy Erkkila and Jay Grossman, eds., Breaking Bounds: Whitman and American Cultural Studies (Oxford University Press, 1996), 62-82.

20 In The Erotic Whitman, Pollak raises interesting questions about gender in relation to this substitutability. To the extent that democratic equality or substitution is based upon professions, it is not clear that it would extend to "mothers" or other women whose labor is defined by gender rather than by work skills-although Whitman names maternal workers in his catalogue beginning "The pure contralto sings in the organloft." This question underlines the extent to which Whitman understands the self collectively and abstractly as both male and as defined by its labor, despite frequent inclusive references to women and female workers or female-associated tasks. In my sketch of Whitman's antebellum poetic, I focus on his vision, not the contradictions that problematize it, because it is the vision that changes. 
21 Matt Miller, "Composing the First Leaves of Grass: How Whitman Used His Early Notebooks," Book History 10 (2007), 110-111. This notebook fragment clearly precedes the "Talbot Wilson" notebook, which Miller authoritatively dates to 1854, because it indicates that Whitman has not yet decided if the work he plans will in fact be a poem.

22 “The Lost Negress of 'Song of Myself' and the Jolly Young Wenches of Civil War Washington," in Susan Belasco, Ed Folsom, and Kenneth Price, eds., Leaves of Grass: The Sesquicentennial Essays (Lincoln: University of Nebraska Press, 2006), 226. Perhaps Price would date this fragment slightly later in response to Matt Miller's dating of what was apparently Whitman's first sketch for Leaves of Grass, especially because in the manuscript Price suggests that Whitman is already writing in poetic lines.

23 Price, 228; Whitman, Daybooks and Notebooks, ed. William White (New York: New York University Press, 1978) 3:762-763.

24 Notebook LC \#80, available at the Library of Congress American Memory website, "The Poet at Work: Walt Whitman Notebooks 1850s-1860s" (http://memory.loc. gov/ammem/wwhtml/080/080068.jpg).

25 Klammer and Folsom write at length about drafts of the Lucifer passage included in "The Sleepers" (1855), where Whitman takes on the voice of a slave openly angry at his mistreatment and hinting at the potential for the black population's destructive revenge. Whitman even took notes for a poem to be called "Poem of the Black person"; see Notebooks and Unpublished Prose Manuscripts, 2:635. Betsy Erkkila argues that 1848 catalyzed a new direction in Whitman's work. She sees "Resurgemus" (1850), one of Whitman's earliest free verse experiments and the only one of his early poems to be published in Leaves of Grass, as celebrating the brief hope of international democracy inspired by the European revolutions of 1848, and hopefully presaging a similar revolutionary change of political direction, generating the "seed of freedom," in the U.S. (51-52). This is one of four poems that Whitman published in 1850 objecting to compromises with slave powers in the U.S. See Erkkila, "Whitman, Marx, and the American 1848," Leaves of Grass: The Sesquicentennial Essays, 35-61.

26 There is also extensive critical commentary on Whitman and race. To mention a few recent arguments in addition to Price's "The Lost Negress," Folsom refers to Whitman's "antebellum desire to voice the subjectivity of the slave, to give the slave power and agency, and to imagine that the poetic act might be enough to . . . coerce the slave masters to recognize the humanity" of the slave; in "Lucifer and Ethiopia: Whitman, Race, and Poetics Before the Civil War and After," Walt Whitman: A Historical Guide, ed. David Reynolds (New York: Oxford University Press, 2000), 52. Taking a somewhat more skeptical view, Klammer argues that "Even at its most radical, Whitman's poetry about slavery sought to produce a poetic of Union that would bring together Northern and Southern whites," asserting that Whitman's racial prejudice was consistent throughout his lifetime; see "Slavery and Race," A Companion to Walt Whitman, 101-121. Jerome Loving argues that around 1855 Whitman began to realize that "life could never be truly improved or reformed except from within" and hence became "poetically serene" and maintained a neutral approach to the question of abolishing slavery (364). This neutrality, however, was based on Whitman's political insistence that the plural states become in fact and not just theoretically "The United States," a single entity (365); see "'A Southerner soon as a Northerner': Writing Walt Whitman's Biography," Leaves of Grass: The Sesquicentennial Essays, 363-377. 
27 I refer to Dickinson's "Pain has but one Acquaintance" (\#1119) and Lanier's "To Our Hills"; The Poems of Emily Dickinson, ed. R. W. Franklin (Cambridge, MA: Harvard UP, 1999), 2:973, and Words for the Hour: A New Anthology of Civil War Poetry, ed. Faith Barrett and Cristanne Miller (University of Massachusetts Press, 2005), 189.

28 Whitman, The Correspondence, ed. Edwin Haviland Miller (New York: New York University Press, 1961), 1:247.

29 In this respect, my argument differs dramatically from Mancuso's, which sees Whitman's pro-Union stance as nostalgic in its mono-vocalism and harking back to the early months of the war. My claim is that by dropping the ideological articulation of his pro-Union stance, Whitman flattens a still relatively complex portrait of multiple responses to the war $(D T, 1865)$ into a simpler and logically incomplete narrative in 1871 .

30 Whitman also focuses "Beat! beat! drums!," "Give me the splendid silent sun," and " 1861 " on Manhattan.

31 For examples of such counting, see "The Stars and Bars" and "Cotton-Doodle" in Words for the Hour.

32 In 1881, Whitman rearranged a few poems, added back some poems omitted (mostly at the end of the sequence), and added two other poems - in other words, revised the sequence far less profoundly, despite the importance of the added poems, "Ethiopia Saluting the Colors" and "Virginia-The West" - both written much earlier but not previously published as part of his Civil War sequences.

33 Mancuso convincingly argues that "A farm picture" has a distinct nostalgic function in normalizing a rural, pastoral scene as "American." It is then, however, puzzling that Whitman would omit this poem in 1871, to my mind the more nostalgic volume.

34 This poem was retitled "Years of the Modern" and moved to another section of Leaves of Grass.

35 As Eldrid Herrington discusses at length, Whitman claims to have "composed," not "strung together," these songs in the 1871 version; see "Fit Compositions: Whitman's Revisions to Drum-Taps," ed. Michael Hinds and Stephen Matterson, Rebound: The American Poetry Book (Amsterdam: Rodopi, 2004), 29-44.

36 "Lo! Victress on the Peaks" is first included in the "Drum-Taps" sequence in 1881.

37 An early version of "Ethiopia Saluting the Colors" was rejected for publication in 1867 and added to Leaves of Grass as part of a different cluster in 1871 (Pollak, 176).

38 Ed Folsom gives a strikingly affirmative reading of this poem in a privately circulated email interpreting "Ethiopia Saluting the Colors" in relation to Barack Obama's election eve speech, which referred to another "ancient" (over one hundred-years-old) black woman who had lived through astonishing historical changes in her lifetime and could no more have predicted the election of a black president than the woman of Whitman's poem could have foretold a national war fought (in part) to liberate her from slavery (personal correspondence November 5, 2008). Nonetheless, it is telling that this is the only poem making any reference to African Americans in relation to the war. See Folsom's extended reading of the poem in "Lucifer and Ethiopia."

39 "Solid, ironical, rolling orb" (DT, 68). Omitted are "Pioneers! O Pioneers!," "Solid, ironical, rolling orb," "Out of the rolling ocean, the crowd," "I heard you solemn-sweet pipes of the Organ," "Not my Enemies ever invade Me," "Camps of 
green," and "Hymn of dead soldiers" (later titled "Ashes of Soldiers"). The primary exception that remains is the five-line "O tan-faced Prairie-boy."

40 Words for the Hour, 328. All other poems quoted in this paragraph are from the same collection of American Civil War poetry.

41 According to Genoways, "Virginia" was published in The Kansas Magazine in 1872 and already drafted in 1861 under the title "Kentucky"; "Civil War Poems in 'Drum-Taps' and 'Memories of President Lincoln," A Companion to Walt Whitman, 523. While it is important to note that Whitman writes poems like "Virginia-The West" and "Reconciliation" before the war's conclusion, it is equally telling that he does not choose to include them in Drum-Taps, despite the fact that both are short poems and he includes several other short poems to fill space. Whitman clearly does not seek to highlight reconciliation in his original printing of the volume.

42 This claim is anticipated in "Solid, ironical, rolling orb"-a four-line poem Whitman omits in 1871: there the world brings "to practical, vulgar tests . . all my ideal dreams" $(D T, 68)$.

43 Whitman: Poetry and Prose, ed. Justin Kaplan (New York: Library of America, 1996), 968-970.

44 As Martin G. Murray points out, Specimen Days also de-emphasizes ideology, partly in the same way, by avoiding mention of the Confederacy-for example, not mentioning that Whitman nursed several confederate soldiers, and especially not that Peter Doyle fought in the Southern army; see "Specimen Days," A Companion to Walt Whitman, 553-565.

45 Useful in this connection is M. Jimmie Killingsworth's argument that Whitman's shift from an antebellum mode of prophecy and preaching to one of witness and reporting may be seen "as an increasing sensitivity to subtle changes in the cultural climate"; see "The Visionary and the Visual in Whitman's Poetics," Leaves of Grass: The Sesquicentennial Essays, 278.

46 This poem was written in 1860 but included in every edition of Drum-Taps. 